\title{
RANCANG BANGUN SISTEM INFORMASI PERPINDAHAN HASIL PRODUKSI KE GUDANG STUDI KASUS PT. MAYORA INDAH TBK
}

\author{
Ivan Nur Amanda \\ Program Studi Informatika Fakultas Teknik, Universitas Muhammadiyah Tangerang \\ J1.Perintis Kemerdekaan I/33, Cikokol, Kota Tangerang \\ Email: ivannuramanda@yahoo.com
}

\begin{abstract}
Abstrak
Kemajuan teknologi informasi yang mengalami perkembangan dari tahun ke tahun mengharuskan kita untuk selalu bergerak maju untuk mengikuti perkembangan ini. Demikian pula dengan PT. Mayora Indah Tbk adalah perusahaan yang bergerak di industri makanan dan minuman. Saat ini proses pemindahan produksi barang ke gudang di PT. Mayora Indah Tbk masih menggunakan sistem manual, dimana tingkat kesalahan yang terjadi sangat besar dan membutuhkan akurasi tinggi. Alasan perancangan konstruksi transfer barang ke gudang menggunakan bahasa pemrograman di PT. Mayora Indah Tbk adalah fasilitas pembelajaran yang memiliki pengetahuan informasi dan teknologi yang mendukung kinerja karyawan, dan membuat sistem lebih mudah, lebih akurat dan praktis. Metode yang digunakan adalah dengan menggunakan Unified Modeling Language (UML) untuk menggambarkan model sistem yang sedang berjalan. Dengan produksi aplikasi ini dapat digunakan sebagai dasar untuk perbaikan sistem yang akan dapat memaksimalkan kerja. Disarankan bahwa sistem yang dapat membantu mempersingkat waktu pemrosesan data, mengatasi masalah kesalahan manusia, dan laporan lainnya perlu diimplementasikan.
\end{abstract}

Kata kunci: Java, Pelaporan, Produksi, Data, Aplikasi.

\section{Abstract}

The advancement of information technology that experiences development from year to year requires us to always move forward to keep up with these developments. Similarly with PT. Mayora Indah Tbk is a company engaged in the food and beverage industry. Currently the process of moving the production of goods to the warehouse at PT. Mayora Indah Tbk still uses manual systems, where the level of errors that occur is very large and requires high accuracy. The reason for designing the construction of the transfer of goods to the warehouse uses programming languages at PT. Mayora Indah Tbk is a learning facility that has information and technology knowledge that supports the performance of employees, and makes the system easier, more accurate and practical. The method used is to use the Unified Modeling Language (UML) to describe the running system model. With the production of this application can be used as a basis for system improvements that will be able to maximize work. It is recommended that a system that can help shorten data processing time, overcome human error problems, and other reports needs to be implemented.

Key words: Java,Reporting, Production,Data, Applications.

\section{PENDAHULUAN}

Perkembangan arus globalisasi yang diiringi dengan perkembangan Teknologi Informasi (TI) menyebabkan arus informasi yang dulunya sulit didapatkan kini dapat dengan mudah diperoleh sesuai dengan kebutuhan. Komputer merupakan suatu perangkat yang sangat dibutuhkan untuk proses penyajian pengolahan data, agar data yang diolah dan dapat memberikan suatu informasi yang diperlukan oleh pimpinan ataupun suatu perusahaan yang membutuhkan.

PT. Mayora Indah Tbk adalah perusahaan industri yang memproduksi 
produk makanan dan minuman olahan. Pada sistem informasi laporan hasil produksi sangatlah penting dalam perusahaan tersebut. Dan sistem yang berjalan saat ini masih mengalami kesalahan dalam hal laporan hasil jumlah barang yang di produksi, sehingga sering terjadinya selisih barang atau data yang berbeda antara produksi dan gudang, karena seharusnya data barang yang dikirim dari bagian produksi harus sama dengan bagian gudang, lalu pembuatan laporan produksi masih terbilang lambat dan penginputan laporan produksi yang berulang dibeberapa bagian. Oleh karenanya teknologi sangat berperan penting dalam terlaksananya proses penginputan data yang lebih cepat, tepat, dan efektif.

Berdasarkan latar belakang yang telah diuraikan, beberapa permasalahan yang dapat diidentifikasi dalam penelitian ini antara lain :

- Proses pengolahan data untuk sistem laporan informasi perpindahan hasil produksi barang dari produksi ke gudang masih menggunakan sistem pembukuan dibeberapa bagian, artinya masih manual sebelum data dimasukan ke komputer, sehingga memperlambat proses penginputan data.

- Pencatatan laporan yang berulang dibeberapa proses bagian laporan produksi barang.

Batasan masalah dalam penelitian ini adalah :

1. Penelitian ini meliputi fitur input laporan hasil produksi

2. Penelitian ini menggunakan Bahasa pemrograman Java untuk pembuatan sistem informasi laporan hasil produksi.

Bagaimana merancang sistem informasi laporan hasil produksi di PT. Mayora Indah Tbk dengan Bahasa pemrograman Java?

\section{TINJAUAN PUSTAKA}

\section{Sistem}

Menurut Jogianto, suatu sistem adalah merupakan jaringan dari prosedur-yang saling berhubungan, untuk melakukan suatu kegiatan atau untuk menyelesaikan suatu sasaran tertentu

Suatu sistem mempunyai karakteristik sebagai berikut :

- Suatu sistem dapat terdiri dari komponen (Component) yang saling berinteraksi yang bekerja sama membentuk satu kesatuan komponen sistem atau elemen

- Batas Sistem (Boundry) yang membatasi antara sistem yang satu dengan sistem yang lainnya.

- Lingkungan luar (Environment)dari suatu sistem diluar batas dari sistem yang mempengaruhi operasi sistem.

- Penghubung (interface) merupakan media penghubung antara satu subsistem dengan subsistem yang lainnya

- Memiliki input yang akan di olah di dalam sistem

- Adanya output yang di hasilkan dari input yang dimasukan ke dalam system

- Suatu sistem dapat mempunyai suatu bagian pengolahan ( Process) yang akan mengolah input berupa data serta bahan-bahan lainnya untuk menghasilkan output berupa laporan ddan informasi yang berguna.

- Sistem pasti mempunyai tujuan(goal) atau sasaran (objective). Kalau suatu sistem tidak mempunyai sasaran maka proses operasi tidak akan ada gunanya.

\section{Informasi}

Menurut Sutanta (2004)

Informasi dapat didefinisikan sebagai hasil pengolahan data sehingga menjadi bentuk yang penting bagi penerimanya dan mempunyai kegunaan sebagai dasar dalam pengambilan keputusan yang 
secara langsung dapat dirasakan akibatnya atau secara tidak langsung pada waktu yang akan datang.

Sistem adalah suatu kumpulan atau himpunan dari unsur, komponen atau variabel yang terorganisasi, saling berinteraksi, saling tergantung satu sama lain dan terpadu. (Permana, 2016).

\section{METODOLOGI PENELITIAN}

Dalam Penelitian ini menggunakan metode pengumpulan data dengan cara observasi dan wawancara di PT. Mayora Indah Tbk untuk mendapatkan infromasi apa yang dibutuhkan dalam membuat sistem informasi koperasi simpan pinjam.

Untuk mengidentifikasi masalah, maka dilakukan analisis terhadap beberapa aspek seperti kinerja, informasi, ekonomi, pengendalian, efisiensi, dan pelayanan. Analisis dengan menggunakan model ini dikenal dengan analisis PIECES (Performance, Information, Economic Control, Efficiency, Service). Hasil dari analisis yang di dapat sebagai berikut :

a. Performance :

- Pembuatan laporan yang belum up to date

- Pengelolaan transaksi perpindahan hasil produksi masih menggunakan pembukuan

- Tidak ada security untuk menjaga keamanan dari data yang dianggap confidential.

b. Information :

Masih adanya kesalahan penghitungan dalam transaksi hasil produksi yang masuk ke gudang

c. Economy :

Proses administrasi produksi masih menggunakan media buku sehingga memerlukan banyak biaya. d. Control :

Perusahaan masih melakukan kontrol laporan hasil produksi secara manual

e. Efficiency :

Efisiensi dalam pembuatan laporan hasil produksi masih kurang informative

f. Service : Pelayanan dalam laporan hasil produksi masih belum optimal.

\section{HASIL DAN PEMBAHASAN}

\section{Analisis Data}

Dari permasalahan yang timbul di atas, ada beberapa alternatif yang bisa diusulkan, seperti :

a. Membuat sistem informasi hasil produksi ke gudang

b. Membuat proses administrasi yang lebih sistematis dalam penggunaannya.

Ada beberapa alasan mengapa sistem ini dibuat dan dikembangkan menjadi aplikasi :

a. Sistem informasi produksi ini dapat memudahkan operator di lapangan dalam seluruh proses administrasi sehingga dapat memperoleh informasi hasil dengan mudah dan cepat.

b. Dengan adanya sistem informasi ini dapat mempercepat proses pengelolaan transaksi hasil produksi ke gudang, karena mudah dalam pencarian data.

Penyajian suatu sistem informasi sedemikian rupa dibuat untuk dapat di akses dengan memanfaatkan teknologi yang ada. Hal ini harus disertai dengan kemudahan dalam pengoperasian dan biaya yang relatif murah.

\section{Economic Feasibility}

Aspek dalam sisi ekonomi meliputi biaya yang dikeluarkan untuk 
membangun sistem dan membandingkan dengan manfaat yang akan didapat setelah sistem koperasi ini akan berjalan. Pengembangan sistem informasi ini dapat dianggap sebagai sebuah investasi jangka panjang yaitu dengan pengeluaran sumber daya yang ada sekarang untuk mendapatkan manfaat diwaktu yang akan datang. Apabila manfaat yang didapat lebih kecil dari biaya yang dikeluarkan, maka pengembangan sistem ini dianggap tidak perlu.

\section{Organizational Feasibility}

Beberapa manfaat yang didapat kan dalam penggunaan sistem informasi ini diantaranya dibagi menjadi:

\section{- Bagi perusahaan}

a. Memudahkan perusahaan dalam mengontrol stok dari laporan hasil produksi.

b. Meningkatkan citra perusahaan dalam komputerisasi proses di bagian produksi.

c. Mendapatkan laporan yang up to date tentang operasional produksi

\section{- Bagi staf produksi}

a. Mempermudah dalam pencarian data sehingga pengelolaan transaksi ke gudang bisa cepat terselesaikan

b. Membantu dalam proses perhitungan transaksi hasil produksi ke gudang sehingga tidak ada lagi kesalahan penghitungan dan pembuatan laporan bisa sesuai tepat waktu.

\section{Activity Diagram}

Activity Diagram adalah diagram untuk menggambarkan aktifitas dari suatu sistem atau proses suatu bisnis, Activity Diagram yang diusulkan untuk proses simpan pinjam sistem koperasi ini sebagai berikut :

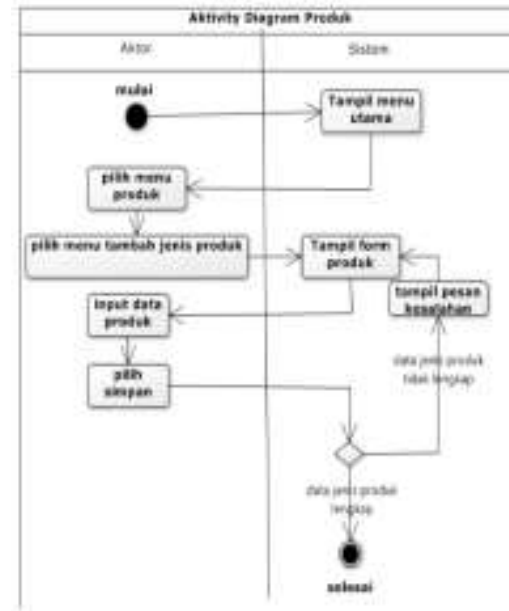

Gambar 1 Activity Diagram proses Produk

Proses ini dimulai dengan staff dari produksi dalam hal ini koordinator melakukan login dengan user dan password yang telah dibuat. Dalam proses ini sistem akan mengecek apakah data login yang dimasukkan sudah benar, apabila ada kesalahan maka sistem akan menampilkan pesan error.

Apabila proses login berhasil, maka akan masuk ke menu utama dari sistem ini. Apabila ingin melakukan proses input hasil produksi maka dipilih тепи produk. Setelah masuk ke menu tersebut maka dimasukkan ID produk dan nama produk

Sistem akan menampilkan dari hasil dari input data produk tadi dan apabila sudah tidak ada kesalahan maka data produk akan disimapn dalam database

\section{Implementasi Sistem}

Implementasi sistem adalah hasil penerapan dari rancangan menu yang telah di buat. Perancangan aplikasi ini menggunakan Bahasa pemrograman Java. 


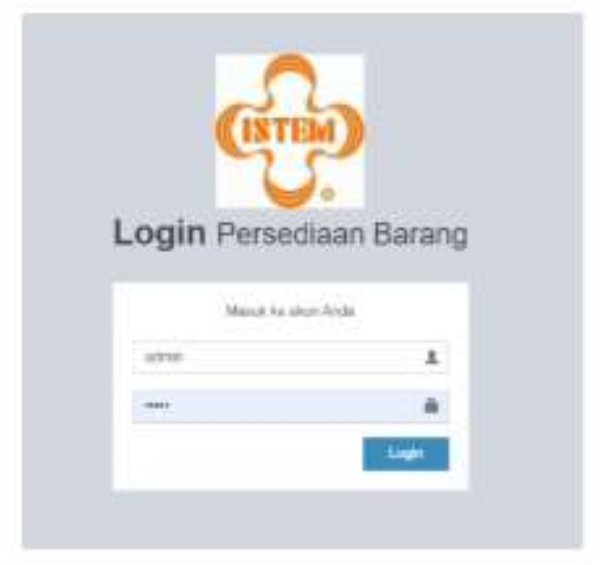

Gambar 2 Tampilan menu Login

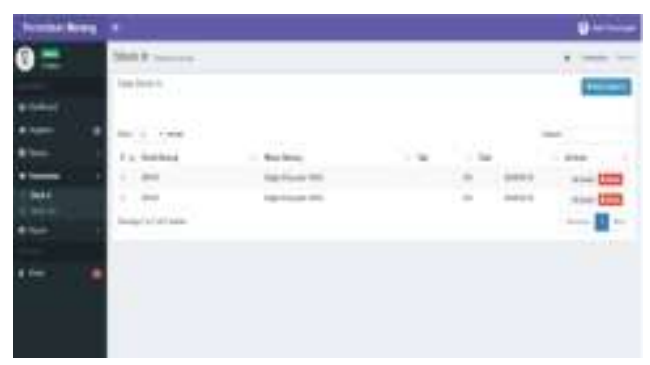

Gambar 3 Tampilan stok Barang masuk Keluar

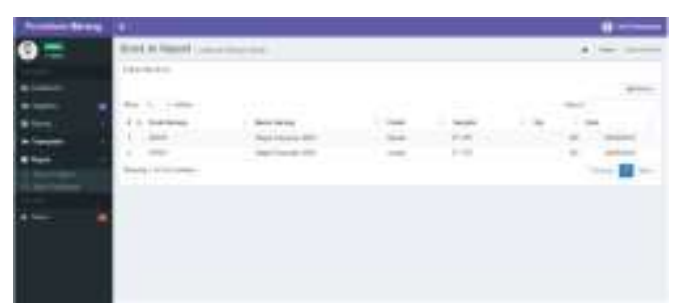

Gambar 4 Form laporan Barang masuk

\section{KESIMPULAN DAN SARAN}

Dengan Aplikasi ini diharapkan proses perpindahan barang jadi dari produksi ke gudang dapat membuat pengolahan data menjadi lebih mudah bagi staff karena sudah terkomputerisasi .Dan pembuatan aplikasi system ini dengan menggunakan Bahasa Pemrograman Java

\section{DAFTAR PUSTAKA}

Ahyari, Agus. (2011). Managemen Produksi: Perencanaan sistem Produksi, Edisi ke lima, Cetakan-4, Jakarta.

Al-Jufri, Hamid (2011). Sistem Informasi Manajemen Pendidikan. Jakarta : Smart Grafika.

Ais Zakiyudin. (2011). Sistem Informasi Manajemen. Edisi 2. Jakarta: Mira Wacana Media.

Gordon B. Davis, Kerangka Dasar Sistem Informasi Manajemen, Cet. IX; Jakarta: Pustaka Binaman Pressindo, (2011).

Herlawati, Prabowo Pudjo Widodo. (2011). Menggunakan UML (Unified Modelling Language). Bandung : Informatika.
Permana,
A.
A. (2016). Rancangan Sistem Informasi Simpan Pinjam Pada Koperasi Guru dan Pegawai SMP Negeri 45 Jakarta. JIKA (Jurnal $\begin{array}{lllll}\text { Informatika) Vol. } 1 & \text { No.2 } 2017\end{array}$ ISSN 2549 - 0710. 